\title{
Karl Goldmark and Czech National Opera: The Final Operas of Antonín Dvořák and Zdeněk Fibich ${ }^{1}$
}

\author{
Jiří KOPECKÝ \\ Department of Musicology, \\ Faculty of Arts of Palacký University Olomouc \\ Univerzitní 3, 77180 Olomouc, Czech Republic \\ E-mail: jiri.kopecky@upol.cz
}

(Received: March 2016; accepted: June 2016)

\begin{abstract}
If Bedřich Smetana is thought to be the father of Czech national opera, Antonín Dvořák and Zdeněk Fibich would be his sons. Czech critics as well as the public expected that Smetana's successors would bring Czech opera to international recognition. Dvořák and Fibich gave increased attention to opera composition during the 1890s and the beginning of the twentieth century. They both crowned their achievements with monumental operas on subjects with historical settings: Fibich's The Fall of Arkona (1900) and Dvořák's Armida (1904). The reason for this apparent coincidence was, in part, that these works were written after Wagner's operas and before the operatic successes of Richard Strauss, when it was possible to devise free combinations of symphonically composed scenes, arioso-like vocal lines influenced by verismo, and the dramaturgical effects of grand opera. As a praised model for successful historical opera might have served Karl Goldmark's famous work Die Königin von Saba, especially in the case of Fibich's last opera, which was explicitly compared with Goldmark's opera. Operas on historical subjects form a little-known part of the works of Czech composers, but they extend from Smetana's piece The Brandenburgers in Bohemia through the late operas of Dvořák and Fibich to Janáček's two-part opera The Excursions of Mr Brouček. It is a line of operas that present an unforgettable counterpart to many successful Czech theatrical compositions - representative operas and intimate tragedies, comic operas and fairy tales, generally written on subjects from Czech villages and mythology, including Smetana's Bartered Bride and Libuše, Fibich's The Tempest and Šárka, Dvořák's Jakobin, Kate and the Devil and Rusalka, Josef Bohuslav Foerster's Eva, as well as Leoš Janáček's Jenůfa.
\end{abstract}

Keywords: Die Königin von Saba, Karl Goldmark, Antonín Dvořák, Zdeněk Fibich

1. This study was written in the frame of the project Osobnosti, druhy a žánry novějši české a evropské hudby (Personalities, kinds and genres of the recent Czech and European Music, IGA_FF_2016_033, Palacký University Olomouc, Czech Republic). 


\section{After the death of Smetana}

Bedřich Smetana (1824-1884) died a year after the opening of the National Theater in Prague in 1883. His eight completed operas provided the foundation of Czech national opera. The next generation of composers inherited a difficult task: to continue in the direction of Smetana's operas, while creating a repertory for an opera stage that would represent the Czech community - a repertory that would be suitable for patriotic themes and demonstrate that it could draw a good audience. These were debates about the prospective repertory of the National Theater even before it was inaugurated. Two opposing sides can be traced in these disputes. The author Jan Neruda advocated - in accordance with his democratic convictions - a variety of genres, so that members of the diverse social and intellectual groups would come to the theater. On the opposite side, aesthete Otakar Hostinský demanded that the repertory be majestic. During the 1880s, the influence of Hostinskýs reasoning led to the composition of operas that were worthy artistically, but unfortunately not financially successful. During the 1890 s, composers turned away from this overly idealistic goal in favor of anticipating the expectations of the Czech public. Nevertheless, the dream of magnificent, tragic historical opera as the highest achievement of the Czech composer clearly would not be shifted entirely to the background. Antonín Dvořák (1841-1904) and Zdeněk Fibich (1850-1900) had the courage to attempt this goal at the height of their creative powers; the task of composing these works took all of their strength. As a result, these operas were their final significant compositions. They crowned their achievements with monumental operas on subjects with historical settings: Fibich's The Fall of Arkona (1900) and Dvořák's Armida (1904).

Otakar Hostinský had advocated Smetana's compositions during Smetana's life as well as after his death. But it is necessary to be aware that, since these operas range from grand opera (The Brandenburgers in Bohemia) to comic opera (The Bartered Bride), conversational opera (Two Widows), romantic tragedy (Dalibor) and a festive tableau (Libuše), it is not really appropriate to say that they "represent a unilateral development based on Wagner, as Hostinský claimed."’ Hostinský was not the only one to indicate the path or resources that would needed for Czech opera to proceed. Smetana himself, who had serious problems with his deafness, recommended Dvořák and Fibich for realisation of demanding tasks. Smetana declined the libretto Ahasver in 1879, leaving it to the two younger composers: "I would suggest either

2. Marta Ottlová, "Bedřich Smetana a Richard Wagner," in Richard Wagner a česká kultura, ed. Pavel Petráněk (Praha: Národni divadlo, 2005), 237. 
Dvořák or Fibich as the composer for Ahasver. Both have enough physical strength to easily take on this laborious task." ${ }^{3}$ Smetana had directed opera at the Provisional Theater, where he knew Dvoŕák as a violist in the theater orchestra. He soon began to notice that Dvořák had a persistent interest in composition. Fibich followed Smetana's example: he devoted himself to symphonic poems and composed operas. His opera Blaník was dedicated to Smetana (1880). On of his later works, Nevěsta messinská (The Bride of Messina, 1884), on a libretto by Otakar Hostinský, in a sense fulfilled Smetana's unrealized plan to give the Czech nation a style of pure musical tragedy. The premiere of The Bride of Messina was a failure, and Fibich did not compose another opera for long afterward. Dvořák did not want to cope with Hostinskýs views and continued to be receptive to different genres of opera (for example, his Dimitrij is written in the style of French grand opera, and his Jakobin is a comic opera). Let us recall that Smetana wrote musical comedies along with his musical tragedies. In 1882, Smetana wrote to Adolf Čech, the chief conductor of the National Theater, that he wanted "to compose for Czech theater a comic opera, in which the technical art of singing predominates!"4 To the end of his life, Fibich had similar plan but was not able to bring it to reality: "He wanted to write opera from modern, contemporary life, in a more conversational style, but with rich, florid melody." 5

Czech composers were also decisively aware that Smetana had not been able to achieve international success for his operas. But less than ten years after Smetana's death, Prodaná nevěsta (The Bartered Bride) began to be performed in German theaters, and from there, it went theaters in France and America. It was apparently not by chance that Dvoŕák and Fibich paid increased attention to opera composition during the 1890s and at the beginning of the twentieth century. The Czech critics and public expected that Smetana's successors would bring Czech opera to international recognition.

\section{Goldmark's Königin von Saba as a model for Czech opera}

The popular operas that Dvořák composed after his return from America (1895) and Hippodamia, Fibich's trilogy of staged melodramas, evolved in direct contact with theatrical praxis. Creators of dramatic works had to respect the requests, recommendations, and orders of Adolf František Šubert, the manager of the National Theater, either voluntarily or against their will. Šubert had learned directly from experience and errors. The baritone Bohumil Benoni well described the inadequacy of Šubert's concept of drama in comparison with that of the New German

3. Roman Veselý, "Smetana a J. V. Frič," Hudební revue 2/5 (květen [= May] 1909), 247.

4. Quoted from Jiří Kopecký (ed.), "Vzpomínka Boleslava Kalenského,” Zdeněk Fibich. Stopy života a dila (Olomouc: Univerzita Palackého v Olomouci, 2009), 97.

5. Anežka Schulzová, “Nejnovější skladby Zdeňka Fibicha,” Národní listy 42/205 (27 July 1902), 13. 
Theater and its excellent manager: "He first had to approach Angelo Neumann and arrange a cycle of Mozart and Wagner in the Prague German theater, so that the manager of the National Theater would be obliged to mount a similar cycle of Smetana operas." ${ }^{\circ} \mathrm{He}$ also observed: "Unfortunately, Neumann found that Šubert imitated his own inferior nature [...]." Šubert tended to be fascinated by spectacles, and often by the financial return of the works he presented; he was not a patron of farces and operettas, but he did favor ballet and epic drama. From the end of the $1880 \mathrm{~s}$, the National Theater could rely on a relatively stable ensemble and a repertory of high quality. This fortunate combination was at its height around $1895^{8}$ when Šubert evaluated his fifteen years as manager of the National Theater, proudly announcing that he would assure a predominance of Czech productions in the next year. ${ }^{9}$ Subert understood how difficult the situation had been in the 1880s, when composers had to adapt their operas to management constraints, and many works had to be rejected. At the height of his career, he was actively determining the new, emerging repertory. In the field of opera, he kept an eye on new, emerging libretti, capturing attractive suggestions and subjects, as well as communicating with the artists that he considered to be the most competent for such work.

It is certain that Fibich's final opera was inspired by Šubert, who stayed in 1896 and 1897 on the island of Rügen. Šbert returned with a subject for a grand opera: the destruction of one of Europe's great Slavic strongholds, which took place on this Baltic Sea island..$^{10}$ Šubert had his eye on Fibich, and evidently expected him to master this extraordinary subject. Šubert had produced Fibich's opera Bouře (The Tempest), and collaborated on the settings of The Bride of Messina, the trilogy of scenic melodrama Hippodamia, and opera Šárka. When Šubert produced Fibich's opera Hedy, he considered its ballet to be one "of the most attractive parts of this work" and emphasized that it needed new, meticulous staging. ${ }^{11}$ Šbert's influence on the musical-dramatic form of The Fall of Arkona extended to implementing the stage machinery of grand opera. A group of letters from Anežka Schulzová to Šubert shows, even though we are not able to know his reactions, that he maintained control of the opera. ${ }^{12}$ In one letter, Schulzová wrote: "[...] I venture to send another act of The Fall of Arkona to be assessed by your esteemed person. I will venture to come in the next few days with a petition concerning your instructions [...]" (letter 2-7). When Šubert decided on the subject, he received the following suggestion:

6. The performance of the first cycle of Smetana operas took place in 1893.

7. Bohumil Benoni, Moje vzpomínky a dojmy I (Praha: B. Kočí, 1917), 137 and 303.

8. Benoni, Moje vzpomínky a dojmy I, 255.

9. František Adolf Subert, Patnáctý rok Národního divadla (Praha: in commission F. A. Urbánek, 1898), 38.

10. František Adolf Šubert, Sedmnáctý rok Národního divadla (Praha: author's edition, 1900), 88.

11. František Adolf Šubert, Dějiny Národního divadla v Praze, 1883-1900 (Praha: Unie, 1908), 413.

12. See Fund 8 H 40 in the Literary archive of The Museum of Czech Literature (Literární archiv Památníku národního písemnictví) in Prague. 
I presume on your kindness, esteemed manager, as soon as the draft of the libretto is ready, - before we begin to work on the individual scenes, which should be done at the same time as the music, - please permit us to send the script to you for assessment. (Letter 3-7, dated 20 June 1898.)

From another lengthy letter (number 4-7), we learn that the idea of a single work consisting of two operas Helga and Dargun, as well as the name of Radana, was Schulzová's. Another letter (5-7) shows that Šubert recommended the "appropriate name from Rügen," that the one-act "overture" Helga, the first of the two-part-opera cycle, met Šubert's requirement that it have a duration of 35 minutes, and that Schulzová influenced the setting for the opera: "I will send you a description of the scenery next week." Fibich and Schulzová eventually dedicated the work to Šubert. Šubert furnished an informative introduction to the separately printed libretto for the entire work, in which he provided documentation that the fall of Arkona was one of the most fascinating and tragic of all epics.

Šubert considered Fibich to be one of "the three greatest that we have"; he was thinking of Smetana, Dvořák, and Fibich. ${ }^{13}$ Naturally, he did not fail to mention his own merit as well:

along with his own ingenious creative strength, Fibich is presented, principally at the National Theater, where his new works are presented with indisputable success $[\ldots] .^{14}$

Fibich thought the National Theater had an almost strategic function. Through it stage, his works could be received throughout the world:

I would urgently ask that at least my last three works: The Tempest, Hedy and Śárka, would remain in the repertory of the National Theater, and I hope that you will kindly not call me immodest for making this request. I would gladly pay to have my operas produced in foreign lands, and that is difficult to acomplish when they are always dropped after a single season at the local theater. ${ }^{15}$

In a confident letter to Šubert from the same year, Fibich lists a long series of guest appearances and adds a decisive argument:

I know that my recent operas are among the best contemporary works in their field, and still the National Theater does not perform them at all. They all van-

13. Šubert, Dějiny Národního divadla, 413.

14. Šubert, Dějiny Národního divadla, 432.

15. Artuš Rektorys (ed.), "Památník Fibichův," Dalibor 32/42-47 (24 September 1910), 315-350 (letter V, 1898, p. 342). 
ish from the repertory after a single season, although according to the report that $\mathrm{I}$ have, a hit is always a big advantage. ${ }^{16}$

\section{In another letter, Fibich again thanked Šubert}

[...] for the valuable support that you kindly gave to my Šárka. I immediately telegraphed Mahler. I would want very much for him to hear my work. It could be a decisive outcome for my work, and my operas thank you for this first success, my esteemed manager, as the operas of Smetana do! $!^{17}$

The direction that the thoughts of the creators of The Fall of Arkona may perhaps be indicated could show by a text written by Schulzová under the pseudonym C. L. Richter. Schulzová reminded the readers of the origin of the new opera (The Fall of Arkona without any doubts):

Meine Bewertung für das, was ich von diesem Werke zu hören bekam, kann ich nicht besser ausdrücken, als wenn ich es mit Goldmark's Königin von Saba in Vergleich stelle.

(If I could appraise this work according to informations which I got, I can not do anything better then to set this opera in comparison with Goldmark's Königin von Saba. $)^{18}$

Schulzová's as well as Šubert's concept was in agreement with the professional opinion of the public. The reputable music critic Václav Juda Novotný, writing about Fibich's opera The Tempest, singled Fibich out for his magical orchestration: „It includes sounds that I have not heard in the orchestra before." And he did not neglect to allude to the passivity of the post-Wagnerian generation when flattering Fibich:

16. Artuš Rektorys (ed.), "Památník Fibichův," letter VI, 1898.

17. Artuš Rektory (ed.), "Památník Fibichův,” letter IX, 1899. Mahler heard Smetana’s Libuše (15 May 1899) and Fibich's Šárka (16 May 1899) in Prague with Růžena Maturová in the principal roles. In order that these performances would have decisive results, Schulzová wrote in her own and Fibich's names to Maturová: "I sincerely hope that Mahler will remain here, especially if you would also kindly put in a good word for us, and how much that would do for you as well!" Artuš Rektorys, red., Zdeněk Fibich. Sborník dokumentů a studií o jeho životě a díle, vol. 2 (Praha: Orbis, 1952), 569. Before this visit, Mahler would have been able to study Fibich's score, which was given to him in Vienna by Fibich's friend Viktor Adam; see Artuš Rektorys (ed.), Zdeněk Fibich, 554; letter from V. Adam to Fibich, 24 January 1899. An undated letter from Schulzová to Šbert gives evidence of his direct contact with Mahler: "We [Schulzová and Fibich] are coming to Vienna tomorrow on musical matters. We would like to take this opportunity to confer a bit with Director Mahler in support of Šárka. Please permit me to ask you that be so kind, with your valuable influence, to give us your support and very kindly to give us you recommendation in this matter.“ (LA PNP, 8 H 40, 6-7).

18. Carl Ludwig Richter, Zdenko Fibich, Eine musikalische Silhouette (Prag: F. A. Urbánek, 1900), 255. 
[...] if we glance through German literature what remains after Wagner's gigantic era, as substantial as Goldmark, after long creative lapses? ${ }^{19}$

The Czech community significantly and automatically associated Fibich with Wagner and Dvořák with old-fashioned opera genres, including French grand opera. These superficially defined categories could also be pushed to their extreme opposites; Fibich could also be called a Meyerbeerian: "In the opinion of the Wagnerian, that would be the worst imaginable designation." ${ }^{20}$ It is just as meaningful to associate Dvořák, usually identified as Meyerbeerian, with Wagnerian intentions. ${ }^{21}$ How can this confusion, which is definitely not typical of Prague musical life, be explained? Did not composers encounter actual post-Wagnerian compositions during the last third of the nineteenth century, including those of Karl Goldmark? Let us recall that Goldmark showed that he could combine Wagnerian "Deklamationsmelos" with bel canto melodies of a Bellini-like character. ${ }^{22}$ His delicate instrumentation created an irresistibly imaginative atmosphere (the strings are divided in up to 14 parts; there are two harps, three flutes, and the percussion section is reinforced with bells, triangle, and other instruments). Goldmark may have modelled the relationship of Assad, Sulamith, and the Queen of Sheba on Wagner's triangle of Tannhäuser, Elisabeth, and Venus; similarly Czech composers could also have been directly influenced by Goldmark. ${ }^{23}$ The libretto of Die Königin von Saba by Salomon Hermann Mosenthal was indebted to the standard of operas by Wagner (primarily Tannhäuser), Meyerbeer (L'Africaine), and Verdi's Aida. Goldmark captivated the public with oriental exoticism, vigorous choruses, effective dance numbers, and scenes presenting a mood of fantasy.

19. [Václav Juda Novotný] (cipher N.), "Bouře,” Hlas národa 62 (3 March 1895). The Fall of Arkona as well as Armida clearly demonstrates that Czech opera was the result of creative work under international as well as domestic influences, that despite, or because of, the effort for national specifications, the result would be part of the current of "Internationalisierung der Oper" during the second half of the nineteenth century. See Sieghart Döhring and Sabine Henze-Döhring, "Oper und Musikdrama im 19. Jahrhundert," Handbuch der musikalischen Gattungen, hrsg. Siegfried Mauser, Bd. 13 (Laaber: Laaber, 1997).

20. Milan Pospíšil, "Nejedlého kritika Dvořáka - operního skladatele,” Opus musicum, 32/6 (2000), 15. It is not inappropriate to observe that Smetana's Dalibor could be considered as "grand opera in the worst style of Meyerbeer [...]" as stated in an anonymous review, Dalibor, 27/39 (30 September 1905), 310.

21. See Miroslav Karel Černý, "Richard Wagners 'Erbe' in der tschechischen Musik nach Bedřich Smetana," in Colloquium Richard Wagner - Nationalkulturen - Zeitgeschichte, ed. Petr Macek (Brno: Masarykova univerzita, 1996), 102-108.

22. See Sieghart Döhring, "Karl Goldmark," in Pipers Enzyklopädie des Musiktheaters, hrsg. von Carl Dahlhaus, Sieghart Döhring, Bd. 2 (München: Piper, 1987), 483.

23. See Fibich's triangle of Jaroměr, Margit, and Radana in The Fall of Arkona and Dvořák's triangle of the prince, Rusalka, and the foreign princess. In Dvořák's Rusalka, we are also reminded of Assad's death in Sulamith's arms as she forgives him. Another direct echo of Königin von Saba can be inferred in Dvořák's Armida. The actions of Fata Morgana, who torments Assad in act IV, scene 3, are not unlike the deception of Fibich's Šárka: "Die abziehende Königin mit ihrem Gefolge erscheint als Gruppe in einer Fata Morgana. Das Bild wird in dem darauffolgenden Sturme verschlungen." Karl Goldmark, Königin von Saba (vocal score; Hamburg: Hugo Pohle, plate number: H. P. 343/267). 
The sources give evidence that Czech composers knew Goldmark's Königin von Saba well and that they considered using it as a model for their own works. Schulzová took Goldmark as her direct model when writing the libretto of The Fall of Arkona; we have Dvořák's own testimony for Armida. At the beginning of 1889, a conversation between Dvořák and Fibich about Wagner's Siegfried resulted in a decision by Dvořák: "[Dvořák] said that he would now compose an opera - not like Siegfried, but somewhat like Libuše or Königin von Saba. “24 Later in 1889, Dvořák evidently was referring to something similar:

Jakobín is written for the people - and they like it. But now I will write something magnificent - I am already thinking about the orchestra - but it must end by $9: 30$ p.m. ${ }^{25}$

The lasting value of Goldmark’s Königin von Saba was also observed by J. B. Foerster in 1915:

The exceptional effect of this work has not wavered to this day. Much has surely faded, much has become public property, many instrumental effects have made their way into other scores, and much colorful magic has become commonplace. Neverthless, much still remains that is strong and superb, so that today, as it was forty years ago, we are ravished and brought into the incandescent, glowing passion of this distinctive, genuine theatrical music. ${ }^{26}$

Last but not least, Goldmark's opera was a favorite of singers as well. The role of the Queen of Sheba is written for a mezzosoprano with an extensive range; there is a $\mathrm{c}^{3}$ in her duet with Assad, act III, scene 3. The supporting roles must also be performed by good singers; for example, the vocal passages sung by the slave Astartoth, act II, scene 2 . The prominent Czech singer Leo Slezak frequently enjoyed performing the tenor role.

It is pertinent that Dvořák and Fibich would have been continually reminded of Goldmark's opera while composing their last operas, for Die Königin von Saba was performed almost without interruption at the National Theater in the 1890s and at the turn of the twentieth century (Table 1). ${ }^{27}$

24. Jiři Kopecký (ed.), “Zápisky Otakara Hostinského,” Zdeněk Fibich. Stopy života a díla (Olomouc: Univerzita Palackého v Olomouci, 2009), 86.

25. Ibid., 87.

26. Quoted from Vlasta Reittererová, Viktor Velek, "K vídeňským létům (1903-1918) Josefa Bohuslava Foerstera," Hudební věda 47/2-3 (2010), 175.

27. Hana Konečná (ed.). Soupis repertoáru Národního divadla v Praze 1881-1983, vol. 1: Soupis repertoáru 1881-1920 (Praha: Národní divadlo, 1983), 41, 72, 121, 192, 215 and 226. 
Table 1 Performances of Die Königin von Saba, Pád Arkuna and Armida in the National Theater

\begin{tabular}{|l|l|c|}
\hline Work & Interval & Performances \\
\hline Goldmark, Die Königin von Saba & 2 April 1886 - 14 March 1888 & 22 \\
\hline $\begin{array}{l}\text { Goldmark, Die Königin von Saba } \\
\text { (new production) }\end{array}$ & 31 August 1888 - 28 July 1891 & 6 \\
\hline $\begin{array}{l}\text { Goldmark, Die Königin von Saba } \\
\text { (new production) }\end{array}$ & 8 October 1893 - 20 February 1900 & 18 \\
\hline Fibich: Pád Arkuna & 9 November 1900 - 4 January 1901 & 7 \\
\hline $\begin{array}{l}\text { Goldmark, Die Königin von Saba } \\
\text { (new production) }\end{array}$ & 14 September 1902 - 3 January 1903 & 13 \\
\hline $\begin{array}{l}\text { Fibich: Pád Arkuna } \\
\text { (new production) }\end{array}$ & 15 October 1902 - 5 January 1905 & 7 \\
\hline Dvoŕák: Armida & 25 March 1904 - 8 September 1904 & 7 \\
\hline
\end{tabular}

After completing Rusalka, Dvořák spent a relatively long time searching for the subject of another opera. Dvořák's prolific experience with work on a large scale led him to believe that it should be an opera with definite potential for international success. The subject of Armida certainly satisfied these conditions, but Vrchlickýs inadequate libretto could have been an obstacle. At the end of the 1880s, Karel Kovařovic was interested in Vrchlický's libretto and the journal Dalibor even published reports during 1888-1895 that he was composing the opera. However, this opera has not survived, if it was actually composed. The entire situation was closely followed by Šubert as the manager of the National Theater; he evidently did not want Vrchlický's work to be abandoned. When the text was finally claimed by Dvořák, he was able to take pleasure that it would be another of "his" works (along with Kate and Devil and Rusalka, which was also inspired through Šubert's intervention). Although Šubert had to leave the National Theater in 1900, his theatrical instinct continued to be a guarantee that the work would be produced..$^{28}$

Dvořák was entirely absorbed in work. Around 14 May 1902, he wrote to Antonín Rezek from Prague to Vienna:

I am now working on a large opera to the words of Jaroslav Vrchlický's Armida and I am happy that after such a long rest that I can work on that which I want, not that what others want. ${ }^{29}$

Dvořák handled the long speeches in the libretto very cleverly, and deleted static scenes; he evidently did not want to admit that it might not be possible to conquer the deficiencies of Vrchlický's poetry. The musical language of Armida is comparable to that of Tannhäuser and Parsifal, but the large form tends to-

28. See Otakar Šourek, Život a dílo Antonína Dvořáka (Praha: Hudební matice Umělecké besedy, 1933), 191.

29. Milan Kuna (ed.), Antonín Dvoř́ák. Korespondence a dokumenty. Korespondence odeslaná, vol. 4: 1896-1904 (Praha: Bärenreiter Editio Supraphon, 1995), 242. 
ward grand opera, with a ballet, marches, processions, a divertissement - and a large double-chorus conclusion to the second act. ${ }^{30}$ The handling of stage music is strikingly successful and naturally integrated into the operatic form in Dvořák's final operas. Examples are the plot of Jakobin which depends on a lullaby; the cantata must be staged as a cantata; Rusalka's song to the moon must be a song, as the dance in Čert a Káča (Kate and Devil) is an actual dance; and the call of the muezzin in Armida must seem authentic. ${ }^{31}$ The musical-dramatic concepts of Dvořák and Fibich during their final years are in striking concordance with the demands of the National Theater, ${ }^{32}$ that is, the demands of Šubert, who definitely did not underestimate the impact of drama on stage design; the box office of the National Theater was assured by epic spectacles and attractive operas like Goldmark’s Königin von Saba.

\section{Between Richard Wagner and Richard Strauss}

Goldmark's Königin von Saba was a genuine hit in its era. Although it is rarely performed today except for a few numbers such as Assad's aria Magische Töne and Sulamith's scene Der Freund ist dein, and is set aside in the category of forgotten treasures like Fibich's The Fall of Arkona and Dvořák's Armida, ${ }^{33}$ it has an authoritative effect in performance. During the era between "Richard the Great" (Wagner) and "Richard II" of German music (Strauss), there was an intensive search for a path to a new operatic form. A strikingly different result was obtained by combining resources of grand opera, symphonic settings of staged works, leitmotif technique and verismo arioso. Composers such as Felix Draeseke, Engelbert Humperdinck, Wilhelm Kienzl and Karl Goldmark were categorized as "between Schumann and Wagner," "Wagnerian school” or "pseudowagnerian," and thirsting for experimentation and fashion. ${ }^{34}$ The historical setting of Königin von Saba can truly serve as a typical "Beispiel für den opulenten Stil des ausgehenden

30. See Jan Smaczny, “"The great little man’: Dvořák and Wagner,” in Wagner in Russia, Poland and the Czech Lands. Musical, Literary, and Cultural Perspectives, ed. Stephen Muir and Anastasia Belinda-Johnson (Burlington: Ashgate, 2013), 116. See also Herrmann Jung, "Grand opéra versus Musikdrama: Zu Antonín Dvořáks letzter Oper Armida (1902-1903)," in The Work of Antonín Dvořák (1841-1904). Aspects of Composition - Problems of Editing - Reception. Proceedings of the International Musicological Conference, Prague, September 8-11, 2004, ed. Jarmila Gabrielová and Jan Kachlík (Prague: Institute of Ethnology, Academy of Sciences of the Czech Republic, 2007), 102-110.

31. See Martin Chusid, "Some Remarks on Stage Music in Dvořák's last operas," in Antonín Dvořák 1841-1991, ed. Marta Ottlová and Milan Pospíšil (Praha: Ústav pro hudební vědu Československé akademie věd, Český hudební fond, 1994), 243-250.

32. See Karel Boleslav Jirák for an analogy between Pádem Arkuna and Dvořák's last opera, Armida; Karel Boleslav Jirák, Zdeněk Fibich (Praha: Orbis, 1947), 30.

33. An isolated presentation is documented by Albrecht's recording of Armida. Pád Arkuna was performed at the National Theater during 2014, the year of Czech music, directed by John Fiore.

34. See a critic on the book by Artur Seidl in Dalibor 24/24 (7 May 1902), 188. 
19. Jahrhunderts" ("example for the pompous style of the late nineteenth century"), ${ }^{35}$ even though Karl Goldmark's sketches were made already in the first half of the 1860 s, and the premiere took place on 10 March 1875 at the Vienna court opera.

The last operas of Fibich and Dvorák entered into the realm of a highly demanding type of composition which included experiments with structurally complex concepts of grand opera. Historical tableaus were often larger than the threeact opera form and required intensive cooperation of the composer, librettist, and stage manager. And the imperfect stage design along with problematic libretti remain an inconvenience for the acceptance of operas such as Smetana's The Brandenburgers in Bohemia, Fibich's Blanik and The Fall of Arkona, Dvořák's Vanda, Dimitrij and Armida, and Janáček's Výlet pana Broučka do XV. století (The excursion of Mr. Brouček to the fifteenth century) as part of the continuing repertory of the National Theater.

Dvořák and Fibich both died around the time of the disappointing premieres of their last operas (Fibich died before the first night of his last opera, Dvořák died soon after the premiere of Armida). Despite exhaustive preparations for the premieres of The Fall of Arkona and Armida, the National Theatre was not able to provide public presentations that would have satisfied their creators. And we can be almost certain that Dvořák would have made further revisions to Armida. His significant creative effort was overwhelmed by the operational problems of the most important Czech operatic stage. The public found a superficial explanation for the failures in the supposition that the death of these composers was connected to the lack of success of their operas on stage.

35. Michael Tegethoff, "Die Königin von Saba," in Lexikon der Oper, ed. Elisabeth Schmierer (Laaber: Laaber, 2002), 800. With a similar context works the paper by Sieghart Döhring, "Dvořáks Armida und die späte Grand Opéra," in Antonín Dvořák, 1841-1991, ed. Marta Ottlová and Milan Pospíšil (Praha: Ústav pro hudební vědu Československé akademie věd, Český hudební fond, 1994), 263-269. 